\title{
AN ASSESSMENT OF CUSTOMER PERCEPTION OF THE BRAND PERSONALITY OF GLOBACOM, NIGERIA
}

\author{
${ }^{1}$ Oladipupo Folorunsho Ajeyalemi, Bolajoko Nkemdillim Dixon-Ogbechie \\ University of Lagos, Lagos (Nigéria)
}

\section{ARTICLE DETAILS}

\section{Article history:}

Received: 25 September 2019

Accepted: 15 July 2020

Available online August: 01 th 2020

\section{Double Blind Review System}

Scientific Editor

Ilan Avrichir

Key words

Brand Personality

Telecommunications Industry

Exploratory Factor Analysis

Confirmatory Factor Analysis

Nigeria

\begin{abstract}
Objective: (i) to adapt Aaker's (1997) scale to measure brand personality in the Nigerian telecommunications market using the methodology identified by Avis (2012) to be the most stable in literature; (ii) to identify the traits that could be used in marketing communication in the telecommunications industry; (iii) to reveal the brand personality factors of the telecommunications industry.

Method: The study used a mixed design and survey method to sample 700 consumers of the Nigerian telecommunications industry. Data was collected using a questionnaire and analyzed using inferential statistics.

Main Results: Aaker's (1997) scale was adapted to measure the brand personality in the Nigerian telecommunications industry and it measured six factors, namely, Sincere, Rugged, Sophistication, Competence, Innovative and Excitement..

Relevance/originality: The study provides local empirical evidence of the brand personality factors of the Nigerian telecommunication industry. The scale will be relevant in measuring the brand personality of other brands within the industry. Theoretical/Methodological contributions: The study supported the use of Aaker's (1997) methodology in developing brand personality scales. The findings were consistent with terminology that could be used to describe brands in the industry. Social Contributions/For management: Managers of Nigerian telecommunication industry brands can make use of the traits identified in marketing communication in order to better present their brands.
\end{abstract}

\section{Introduction}

Customer's willingness to pay for telecommunications service relies on the value such a customer attaches to that service. Consumption of telecommunication services can either be functional or symbolic (Ekinci, Sirakaya-Turk \& Baloglu, 2007). It is not uncommon to see many telecommunication brands focussing on the functional benefits of their service such as boasting of fast internet service or guaranteeing quality voice calls. However, symbolic consumption may be a more useful tool to help to drive increased customer loyalty (Kim, Kim \& Holland, 2018). This is because symbolic consumption can represent the values and beliefs of a culture (Aaker et al, 2001) as well as allowing the customer to be selfexpressive (Keller, 1993). This self-expression may take the form of identifying with values the brand has stood for or aspiring towards a lifestyle promoted by the brand and has been found to be a significant predictor of customer loyalty (Ekinci, Sirakaya-Turk \& Preciado, 2013). Brand personality has been

\footnotetext{
${ }^{1}$ Contact of the author Email: oajeyalemi@unilag.edu.ng
}

identified as a driver of symbolic consumption (Chi, Pan \& Del Chiappa, 2018; Usakli \& Baloglu, 2011). Thus is can be a useful tool in driving customer loyalty for telecommunication brands as it can help to develop marketing communication that can engage customer self and lifestyle congruity and increase the chances of loyalty. However, Aaker (2001) and Aaker, Benet-Martinez, \& Garolera, (2001) explained how brand personality's symbolic and expressive attributes associated with commercial brands are structured and how this structure varies across various countries with seemingly different cultures and discovered that although the utilitarian attributes of commercial brands tend to exhibit limited variability in meaning or importance across cultures, the symbolic or value-expressive functions (the brand personality) associated with a brand tend to vary to some degree because of the variation of individuals' needs and self-views and socialization. This suggests that there in a need to need to empirically investigate Brand Personality across various product categories and cultures as there may be variations from Aaker's 
original five dimensions which were measured in the American context. This is also supported by Hosany, Ekinci \& Uysal (2006) who argued that cultures that are quite different in their values and needs are more likely to exhibit culture-specific differences in brand personality.

Brand Personality has been measured empirically using both quantitative and qualitative research designs (Avis, 2012) with quantitative methods being mostly dominated by Aaker's (1997) methodology (Freling, Crosno \& Henard, 2010), and so far, only two qualitative methods being found (Avis, 2012). This study aims to measure Brand Personality within the Nigerian context by adopting the widely used Aaker's (1997) methodology in scale development and measurement. The Nigerian market is the largest economy in Africa (Naidoo, 2020). Which provides justification for carrying out the study in Nigeria. Moreover, such a study can be replicable in any other country.

The Nigerian Communications Commission (NCC) (2020) reported that the Nigerian Global System for Mobile Communications (GSM) market is one of the fastest growing markets in the world contributing about $10 \%$ of the National GDP. However, the industry has been lagging other sectors in terms of customer satisfaction and loyalty as argued by Oghojafor, Ladipo, Ighomereho \& Odunewu (2014). In their analysis of the sector, Sanusi, Ajilore \&Oloyede (2014) identified the biggest players in the industry ('The Big Four") as - MTN Nigeria, Glo Mobile (Globacom), 9Mobile and Airtel Nigeria. Furthermore, researchers have studied the Nigerian telecommunications industry from a variety of marketing viewpoints including Advertising and Brand Loyalty (Sanusi, Ajilore \& Oloyede, 2014); Corporate Communication and Brand Image (Onikoyi \& Onikoyi, 2013); Customer Satisfaction and Loyalty (Oghojafor et al., 2014); Aggressive Marketing and Product Performance (Obasan, Ariyo \& Soyebo, 2013), however, not much seems to have been done in the area of brand personality. This research will fill provide some insight to the perception of consumers within the Telecommunications industry to the Glo Mobile Brand which is owned by Globacom Telecommunications (Nig.) Limited. It will also develop a framework that can be replicated in other cultures. The Glo Mobile Brand has been chosen as it is the only brand out of the Big Four - MTN Networks Nigeria Limited, Airtel Nigeria Limited, Etisalat Networks Nigeria Limited and Globacom
Telecommunications Nigeria Limited, which appears to be wholly Nigerian, owned and developed. It is hoped that this fact would have infused it with wholly Nigerian values and needs.

This study contributes to the brand personality literature in three ways, first it adapted Aaker's (1997) scale to measure brand personality in the Nigerian telecommunications market using the methodology identified by Avis (2012) to be the most stable in literature; second, it identified the traits that could be used in marketing communication in the telecommunications industry; and finally, it revealed the brand personality factors of the telecommunications industry. The rest of the paper is structured thus: After reviewing the extant literature, the methodology employed was explained. This was followed by results and findings. Subsequently, discussions were elaborated upon. The study concludes with managerial implication for telecommunications managers and marketing professionals.

\section{Literature Review}

\section{Aaker's (1997) Dimensions of Brand Personality}

Consumers associate with brands that reinforces their social identity and add values to their reputation. People tend to have social connections with groups and organisations, and in many instances, their relationship or association with brands is a function of personal identity, self-concept and quite importantly, social identification with groups. Consumers identify with brands that ensures a sense of belongingness especially among groups they belong to or aspire to belong (Chua, Lee, Kim \& Han, 2017; Kim, Kim, \& Holland, 2018). Consumers decisively choose brands and products that they perceive are consistent with their own image of selfidentity and congruent with their own personality (Kressman, Sirgy, Herrmann, Huber, Huber, \& Lee, 2006; Lu \& Xu, 2015). Understanding personalities of brands has become more crucial due to increase in customers' awareness about available alternatives (Chi, Pan, \& Del Chiappa, 2018; Ekinci \& Hosany, 2006). This was buttressed by Sheena and Naresh's (2012) assertion that a brand without personality has trouble gaining awareness and developing relationship with customers. Brand personality has been examined from various points of view since Aaker's seminal work on dimensions of brand personality. It was investigated as an independent 
variable by Wang, Yang, and Liu (2009) who studied the effects of brand personality on purchase intention and found that strong and positive productbrand personality can exert significant influence on consumer purchase intention and also as a dependent variable by Seimiene and Kamarauskaite (2014) who used a qualitative interview to study the effects of brand elements on brand personality. It has also been investigated on a variety of product categories. For instance, Merabet and Benhabib (2012) examined the brand personalities of cars and soft drinks while Pantin-Sohier, Decrop and Brée (2005) investigated the effects of changes in product packaging of mineral water and tinned coffee on customer perception of their brand personality. Brand personality has also been assessed in terms of places, states or countries such as Geuens, Weijters and De Wulf's (2009) study within the Belgian context and Hultman, Skarmeas, Oghazi and Beheshti's (2015) study of Las Vegas where they found that brand personality is a determinant not only of customer satisfaction and promoting, but also of repurchase intentions. Brand personality can also be used for differentiation within industries as shown by Carlson, Donovan and Cumisky (2009) in their study on the sports industry and Ekinci, Sirakaya-Turk and Preciado (2013) in their assessment of the tourism industry. This suggests evidence that brand personality may be a useful tool in providing differentiation in the telecommunications industry.

\section{Scale Development and Brand Personality}

Avis (2012) presented a few models of brand personality developed using various methodology (qualitative and qualitative) noting that it is surprising to see the degree of variability amongst the models, when each model was developed with similar methods and concluded that Aaker's (1997) methodology appeared to be the most dominant and stable method of all existing methods. This is supported by several other researchers such as Usakli and Baloglu (2011); Geuens, Weijters \& De Wulf (2009); Muniz (2012) who have developed scales of their own using Aaker's Methodology.

Furthermore, Ivens and Valta (2012) prepared a taxonomy of Brand Personality research, and identified various groups of selected research built on Aaker's Methodology. These groups varied in the way brand personality featured in the research. They identified research on cross- country similarities and differences in consumer perception of Brand Personality, research on cross-industry similarities and differences in consumer perception of Brand Personality, as well as research linking the brand personality construct to various outcome variables. This suggests that the Brand Personality construct can be measured in various ways and for varying reasons according to Ivens and Valta (2012). Their findings also provide a basis for the development of a scale within the Nigerian context for a wholly Nigerian brand within the telecommunications industry as a search of three databases (EBSCOHost, Jstor and ScienceDirect) which are available to the researcher as at the time of the study do not reveal any previous research carried out within the Nigerian context. Even though literature search revealed that only two (ie. Opoku, Abratt \& Pitt, 2006; Pitt, Opoku, Hultman, Abratt, \& Spyropoulou, 2007) carried out within the African Context in general.

This study, therefore, attempts to bridge the lacunae of knowledge in the perception of Brand Personality in the Nigerian consumer market.

\section{Method}

The study employed a Quantitative Research design in line with Avis's (2012) assertion that quantitative methods are more stable when measuring brand personality.

\section{Population and Sampling}

The population for this study was consumers of the Nigerian telecommunication industry resident in Lagos State, which is a melting pot of all the Nigerian cultures due to its designation as Nigeria's economic focal point (About Lagos, n.d.). Klabi and Debabi (2011) as well as Čáslavová and Petráčková (2011) supported this category of subjects. In line with Aaker's (1997) use of non-probabilistic volunteer sampling 700 volunteers who were all students of the University of Lagos Distance Learning Institute completed copies of the questionnaire. Students were used as they are customers of the telecommunications industry which were immediately accessible to the researchers. in line with Aaker's (1997).

\section{Instrumentation and Validity}

The data was collected using a self-administered survey questionnaire, which was distributed to all 
sample subjects. The questionnaire was developed in line with Aaker's (1997) methodology using 6 academic scholars in the field of Business Administration to undergo free association tasks to develop 5 traits each peculiar to the Nigerian Cultural Context, which were added to Aaker's (1997) Brand Personality Scale. Redundancies and close synonyms were eliminated using two separate online thesauruses. The resulting list was then given to two senior lecturers teaching postgraduate courses in the Marketing Program of the University of Lagos for face and content validation and possible elimination of traits not relevant to the telecommunications industry. This process generated a list of 48 items, which were considered valid for the study. 39 of the original Aaker's 42-item scale) (small town, western and good-looking were not adjudged to describe the telecommunications industry) were retained and 9 new traits - Innovative, Indigenous, Efficient, Effective, Distinct, Competitive, Diligent, Responsive and Accessible were generated. A 5-point descriptive rating scale $(5=$ Very Descriptive, $1=$ Not at all descriptive) was used to collect responses about the generated traits; this is in line with Aaker (1997) use of such a scale.

\section{Data Analysis}

The data was analysed using Exploratory Factor Analysis to extract the major dimensions while traits in each dimension were further Factor Analysed to determine the facets. This is in line with Aaker's (1997) methodology. Confirmatory Factor Analysis was used to validate findings, this method of analysis has also been used by Chi, Pan and Del Chiappa (2018) as well as Geuens, Weijters and De Wulf, (2009).

\section{Results and Discussion}

\section{Demography of Respondents}

The sex of respondents was evenly distributed with $50.1 \%$ of respondents being male and $49.9 \%$ being female. Age range of respondents also appeared normally distributed with $80 \%$ of the respondents being between 26 and 40 years old. Marital Status was also evenly spread with up to $51.3 \%$ being single and $46.9 \%$ being married.

\section{Exploratory Factor Analysis}

The Exploratory Factor Analysis was carried out using Principal Component Extraction with a VARIMAX Rotation and latent root criterion (eigenvalues $>1$ ) (Usakli \& Baloglu, 2011), on SPSS 20 Software. All loadings less than 0.5 were suppressed as recommended by Hair, Anderson, Tatham and Black (2005), since factor loadings greater than .50 are considered necessary for practical significance. Some traits not loading up to 0.50 were dropped. Table 1 presents the factor loadings. 
Table 1 Factor Loadings

\section{Rotated Component Matrix ${ }^{\mathrm{a}}$}

\begin{tabular}{|c|c|c|c|c|c|}
\hline & & & mponent & & \\
\hline & 1 & 2 & 3 & 4 & 5 \\
\hline Successful & .686 & & & & \\
\hline Corporate & .686 & & & & \\
\hline Leader & .673 & & & & \\
\hline Technical & .646 & & & & \\
\hline Intelligent & .639 & & & & \\
\hline Confident & .581 & & & & \\
\hline Independent & .576 & & & & \\
\hline Hardworking & .557 & & & & \\
\hline Secure & .546 & & & & \\
\hline Upperclass & .530 & & & & \\
\hline Sincere & & .711 & & & \\
\hline Real & & .709 & & & \\
\hline Honest & & .683 & & & \\
\hline Wholesome & & .662 & & & \\
\hline Cheerful & & .639 & & & \\
\hline Original & & .590 & & & \\
\hline Family-Oriented & & .565 & & & \\
\hline Friendly & & .538 & & & \\
\hline Sentimental & & .510 & & & \\
\hline Indigenous & & & .724 & & \\
\hline Innovative & & & .704 & & \\
\hline Efficient & & & .704 & & \\
\hline Distinct & & & .677 & & \\
\hline Effective & & & .653 & & \\
\hline Competitive & & & .527 & & \\
\hline Dilligent & & & .505 & & \\
\hline Tough & & & & .777 & \\
\hline Masculine & & & & .774 & \\
\hline Outdoorsy & & & & .680 & \\
\hline Rugged & & & & .663 & \\
\hline Feminine & & & & .642 & \\
\hline Contemporary & & & & .541 & \\
\hline Young & & & & & .720 \\
\hline Spirited & & & & & .670 \\
\hline Cool & & & & & .657 \\
\hline Exciting & & & & & .653 \\
\hline Imaginative & & & & & .611 \\
\hline Unique & & & & & .571 \\
\hline
\end{tabular}

Extraction Method: Principal Component Analysis.

Rotation Method: Varimax with Kaiser Normalization.

a. Rotation converged in 7 iterations.

Source: SPSS Output 
The results initially showed a 6 -factor model, however, one of the factors only had one item and was subsequently dropped in line with Raubenheimer's (2004) recommendation of a minimum of 3 items per factor. Thus, a 5 -factor model (See Figure 1), which explained about $66 \%$ of the Total Variance, which is within accepted levels was adopted. The Kaiser-Meyer-Olkin Measure of
Sampling Adequacy was sufficient (0.969) suggesting that the Principal Component Analysis was appropriate to use on the data (Usakli \& Baloglu, 2011). The Bartlett's Test of Sphericity (Table 2, $p$ value $<0.01$, Chi Square $=13676.488, \mathrm{df}=703$ ) suggested that there existed enough correlations between the variables to run a factor analysis and that there was a good model fit (Aaker, 1997).

Table 2 KMO Statistics

KMO and Bartlett's Test

\begin{tabular}{|c|c|c|}
\hline \multicolumn{2}{|c|}{ Kaiser-Meyer-Olkin Measure of Sampling Adequacy. } & .969 \\
\hline \multirow[t]{3}{*}{ Bartlett's Test of Sphericity } & Approx. Chi-Square & 13676.488 \\
\hline & df & 703 \\
\hline & Sig. & .000 \\
\hline
\end{tabular}

Source: SPSS Output

\section{Reliability}

The reliability test carried out using Cronbach's Alpha showed high reliability of each factor (Aaker, 1997). The researchers further carried out an ANOVA test using the F-Statistic, which was also found to be significant $(p<0.01)$ which corroborates the goodness of model fit. Individual item reliability also tested highly as the corrected item-total correlation showed high correlations all above 0.50 . The findings of these tests suggest that the scale is reliable and also suggests good validity. All reliability results are presented in Table 3.

Table 3: Brand Personality of Globacom (Nig.) Limited

\begin{tabular}{|l|l|l|l|l|}
\hline Brand Personality of Globacom (Nig.) Limited \\
\hline Sincerity & Ruggedness & Competence & Excitement & Innovation \\
\hline Sincere & Tough & Successful & Young & Innovative \\
Real & Masculine & Corporate & Exciting & Indigenous \\
Wholesome & Rugged & Technical & Spirited & Efficient \\
Honest & Feminine & Leader & Cool & Effective \\
Cheerful & Outdoorsy & Independent & Imaginative & Distinct \\
Original & Contemporary & Intelligent & Unique & Competitive \\
Friendly & & Hardworking & & Dilligent \\
Family- & & Confident & & \\
Oriented & Secure & & \\
Sentimental & & Upper-class & & \\
\hline Source: SPSS Output
\end{tabular}

Validity of the Scale

Analysis to test the stability of the scale using confirmatory factor analysis suggested a there might not be good model fit with a significant chi square value of $\chi 2=2201.95, \mathrm{df}=688, \mathrm{p}=0.000 \chi 2 / \mathrm{df}=$ 3.20051163. However, according to Hooper,
Coughlan and Mullen (2008) chi square can be very sensitive to large sample sizes, this is also supported by Kline (2005). This suggests the need for a look at other indices. RMSEA (RMSEA $=0.59$ ) value was within the acceptable range of 0.50 and 0.80 (Hair et al, 2005). CFI (.909) was above Kline's (2005) (>.90) suggestion and SRMR (0.065) values were also less to 
0.08, which was adjudged to be acceptable by Hu and Bentler (1998, 1999). Thus in accordance with the criteria set by Hair et al (2005) and supported by
Hooper, Coughlan and Mullen (2008), the convergent validity of the scale is confirmed. Figure 1 presents a graphical representation of the 5-Factor model.

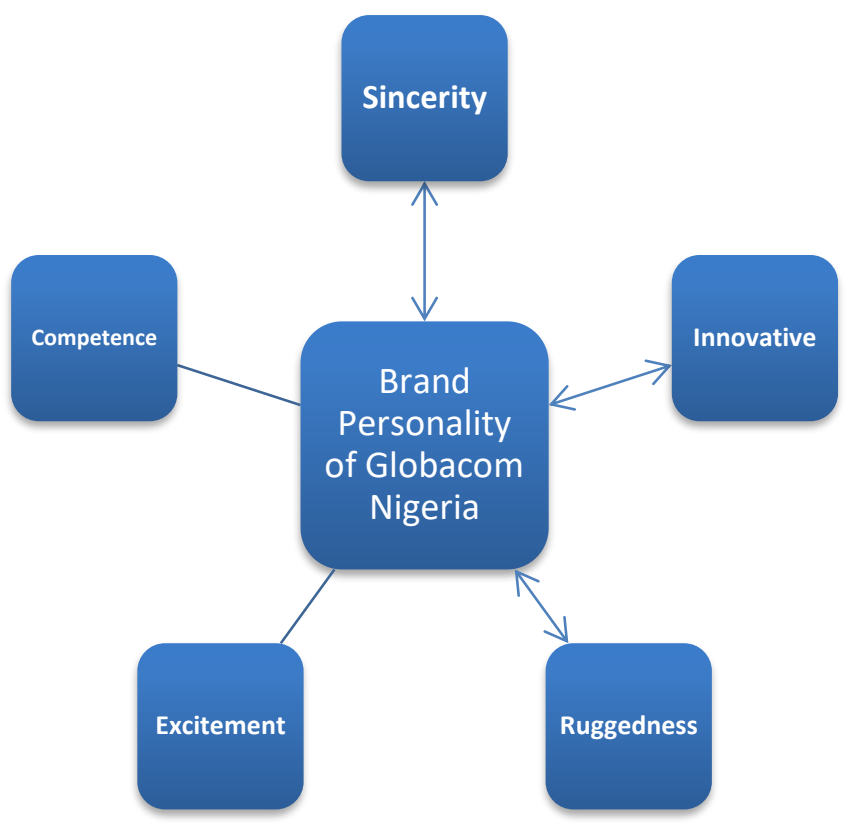

Figure 1-5-Factor Model

\section{Brand Personality Dimensions for Globacom Nigeria Limited}

The 5-factor model had three factors that show significant similarity to three of Aaker's (1997) Dimensions. For instance, Aaker's Competence Dimension was well represented in the 6- Factor model with many of its original traits loading well for under one factor. Interestingly however, the reliable trait was removed while independent and upper-class appeared to load higher under this factor. This may be explained by the Nigerian belief of upscale labels as a sign of competence over lower scale brands. The Sincerity Dimension also loaded reasonably the same with only the down-to-earth trait being removed completely due to low loading. All other traits from the original Sincerity Dimension loaded highly in our 6-Factor model. Another similar factor was the Ruggedness Dimension, which loaded all original traits but also added the contemporary trait, which had previously loaded on the Excitement Dimension on Aaker's Model. Aaker's Excitement Dimension was seen to drop quite a lot of its traits due to low loading with traits like daring, trendy and up-to-date being dropped entirely while the independence trait loaded higher for the Competence Dimension and the contemporary trait loaded higher under the Ruggedness Dimension. An entirely new factor however emerged with all its traits loading highly (0.514 - 0.700). This new factor we have named Innovative. This is because it is made up of traits that can connote innovation such as - distinct, effective, innovative, competitive, diligent, and indigenous. All these traits can be said to fit rather well with a brand for an organization that is supposed to have a high dependency on technological advancement such as one in the telecommunications industry in which our study belongs. This also lends credence to our claim of a good model fit. Table 4 presents the various factors along with the traits that loaded under them. 
Table 4 Reliability Statistics

\begin{tabular}{|l|l|l|l|l|}
\hline Construct & $\begin{array}{l}\text { Cronbach's } \\
\text { Alpha }\end{array}$ & $\begin{array}{l}\text { Initial } \\
\text { Items }\end{array}$ & $\begin{array}{l}\text { Items } \\
\text { Accepted }\end{array}$ & Items Dropped \\
\hline Competence & .883 & 9 & 6 & 3 \\
\hline Excitement & .897 & 6 & 5 & 1 \\
\hline Innovation & .882 & 7 & 7 & 0 \\
\hline Ruggedness & .881 & 5 & 4 & 1 \\
\hline Sincerity & .892 & 9 & 8 & 1 \\
\hline
\end{tabular}

Source: SPSS Output

\section{Implication for the Telecommunication Industry}

This study has revealed traits which may be used in marketing communication within the telecommunication industry. This may prove valuable to marketers managing the brands of such organisations. Some of the traits of the Innovation factor such as diligent or effective can be used to create the impression of good quality service. Additionally, the scale can be used to measure how well the individual organisations are managing their brands in line with the factors revealed. Such measurement can guide the managers of such brands modifying the marketing process. In Nigeria specifically, exploring the performance of Globacom Nigeria's brand personality can yield avenues for the organisation to modify it's marketing communication to better position it in the minds of the customers.

\section{Conclusion}

The aim of this study was to explore brand personality dimensions in the Nigerian context, by adapting Aaker's(1997) scale to the Nigerian telecommunications industry. It also provides support for the use of Aaker's methodology in the measurement of brand personality. The study also revealed some of the traits that can be used in marketing communication by marketing professionals in the telecommunications industry such as Family-Oriented to connote that the brand has family values or Successful to show that the brand is acceptable to high income earners.

Furthermore, this study employed a confirmatory approach, making it possible to achieve a glimpse of the perception that consumers have of the Globacom Brand as a wholly Nigerian Brand, enabling the identification of the dimensions of brand personality which were labelled as Competence, Sincerity, Ruggedness, Innovative, Sophistication and Excitement.
Findings of this study made it possible to compare the Nigerian dimensions to those found in other contexts, which underlines the proposition that consumer symbols such as brands can carry different and sometimes varying meanings between cultures thus reconfirming culturally significant meanings of a given culture (Aaker et al., 2001). The findings support that of authors studying across various cultures (Glińska \& Kilon, 2014; Hosany, Ekinci \& Uysal, 2006; Sung and Tinkham, 2005).

\section{Limitations and Further Research}

This study was limited to only one brand within the Nigerian Telecommunications Industry due to the need to assess a brand that was wholly owned by Nigerians in order to see if such a brand perceived as wholly Nigerian could exhibit cultural inferences that would indicate a dimensional shift from Aaker's (1997) dimensions. Future research can focus on more brands within the industry to get a more generalized view of Brand Personality perceptions of the industry as a whole.

This study also concentrated on only one product category in accordance with Glińska \& Kilon (2014) while researchers such as Aaker (1997) and Muniz (2012) measured Brand Personality across various product categories. Thus, future research can include other product categories within the Nigerian context.

\section{References}

Aaker, J. L. (1997). Dimensions of brand personality. Journal of Marketing Research, 34, 342352.

Aaker, J.L., Benet-Martinez, V., \& Garolera, J. (2001). Consumption symbols as carriers of culture: A study of Japanese and Spanish brand personality constructs. Journal of Personality and Social Psychology, 81,492-508. 
Avis, M. (2012). Brand personality factor based models: A critical review. Australasian Marketing Journal, 20(1), 89-96.

Budaev, S. V. (1999). Sex differences in the Big Five personality factors: Testing an evolutionary hypothesis. Personality and Individual Differences, 26, 801-813.

Carlson, B. D., Donavan, D. T., \& Cumiskey, K. J. (2009). Consumer-brand relationships in sport: brand personality and identification. International Journal of Retail \& Distribution Management, 37(4), 370384.

Čáslavová, E., \& Petráčková, J. (2011). The Brand Personality Of Large Sport Events, 43, 91-106.

Chan-Olmsted, S. M., \& Cha, J. (2007). Branding Television News in a Multichannel Environment: An Exploratory Study of Network News Brand Personality. International Journal on Media Management, 9(4), 135-150.

Chan-Olmsted, S. M., \& Cha, J. (2008). Exploring the Antecedents and Effects of Brand Images for Television News: An Application of Brand Personality Construct in a Multichannel News Environment. International Journal on Media Management, 10(1), 32-45.

Chi, C. G. Q., Pan, L., \& Del Chiappa, G. (2018). Examining destination personality: Its antecedents and outcomes. Journal of Destination Marketing \& Management, 9, 149-159.

Chua, B. L., Lee, S., Kim, H. C., \& Han, H. (2017). Investigating the key drivers of traveler loyalty in the airport lounge setting. Asia Pacific Journal of Tourism Research, 22(6), 651-665.

Costa, P.T. \& McCare, R.R. (1992). Professional Manual for the NEO-PI-R and NEO-FFI. Odessa, FL: Psychological Assessment Resources.

De Moya, M., \& Jain, R. (2013). When tourists are your "friends" : Exploring the brand personality of Mexico and Brazil on Facebook. Public Relations Review, 39(1), 23-29.

Ekinci, Y., \& Hosany, S. (2006). Destination personality: An application of brand personality to tourism destinations. Journal of Travel Research, 45(2), 127-139.

Ekinci, Y., Sirakaya-Turk, E., \& Preciado, S. (2013). Symbolic consumption of tourism destination brands. Journal of Business Research, 66(6), 711-718.

Eysenck H.J. \& Eysenck, M. W. (1985). Personality and individual differences: a natural science approach. New York: Plenum Press.

Freling, T.H., Crosno, J.L. \& Henard, D.H., (2010). Brand personality appeal: conceptualization and empirical validation. Journal of the Academy of Marketing Science 39 (3), 392-406.

Geuens, M., Weijters, B., \& De Wulf, K. (2009). A new measure of brand personality. International Journal of Research in Marketing, 26(2), 97-107. http://doi.org/10.1016/j.ijresmar.2008.12.002

Glińska, E., \& Kilon, J. (2014). Desirable Traits of the City Brand Personality in the Opinion of Managers for the Promotion of the City Government in Poland1. Procedia-Social and Behavioral Sciences, 156(April), 418-423.

http://doi.org/10.1016/j.sbspro.2014.11.214

Griffiths, C. (1991). Personality and secondlanguage learning: Theory, research, and practice. [Online] Available: http://www.eric.ed.gov/PDFS/ED367167.pdf (March 10, 2011)

Hair, J. F., Jr., Anderson, R. E., Tatham, R. L., \& Black, W. C. (2005). Análise multivariada de dados. Porto Alegre: Bookman

Hooper, D., Coughlan, J. \& Mullen, M.R. (2008). Structural equation modelling: guidelines for determining model fit. Electronic Journal of Business Research Methods. 6 (1), 53-60.

Hosany, S., Ekinci, Y., \& Uysal, M. (2006). Destination image and destination personality: An application of branding theories to tourism places. Journal of Business Research, 59(5), 638-642.

Hu, L.T. \& Bentler, P.M. (1998). Fit indices in covariance structure modeling: sensitivity to underparameterized model misspecification. Psychological Methods, 3, 424-453. 
Hu, L.T. \& Bentler, P.M. (1999). Cut-off criteria for fit indexes in covariance structure analysis. Conventional criteria versus new alternatives. Structural Equation Modeling, 6, 1-55.

Hultman, M., Skarmeas, D., Oghazi, P., \& Beheshti, H. M. (2015). Achieving tourist loyalty through destination personality, satisfaction, and identification. Journal of Business Research.

Ivens, B. and Katharina S. Valta (2012), Customer Brand Personality Perception: A Taxonomic Analysis, Journal of Marketing Management, 28, 9/10, 10621093.

Keller, K. L. (1993). Conceptualising, measuring and managing customer-based brand equity. Journal of Marketing, 57, 1e22.

Kim, S. H., Kim, M., \& Holland, S. (2018). How customer personality traits influence brand loyalty in the coffee shop industry: The moderating role of business types. International Journal of Hospitality \& Tourism Administration, 19(3), 311-335.

Klabi, F. \& Debabi, M. (2011). Brand Personality and Emotional Attitudes: The Case of Mobile Telephone Operators, 245-262. http://doi.org/10.1080/08911762.2011.592460

Kline, R.B. (2005), Principles and Practice of Structural Equation Modeling. New York: The Guilford Press.

Kressmann, F., Sirgy, M.J., Herrmann, A., Huber, F., Huber, S., \& Lee, D.J. (2006). Direct and indirect effects of self-image congruence on brand loyalty. Journal of Business Research, 59(9), 955-964.

Kumar, V., \& Nayak, J. K. (2014). The measurement \&amp; conceptualization of destination personality. Tourism Management Perspectives, 12, 88-93.

Lu, J., \& Xu, Y. (2015). Chinese young consumers' brand loyalty toward sportswear products: A perspective of self-congruity. Journal of Product \& Brand Management, 24(4), 365-376.

Levy, S. J. (1985). Dreams, fairy tales, animals, and cars. Psychology \& Marketing, 2, 67-8 1
Markus, H.R. \& Kitayama, S. (1998). The cultural psychology of personality. Journal of Cross Cultural Psychology, 29(1), 63-87

Mathur, P., Jain, S. P., \& Maheswaran, D. (2012). Consumers' implicit theories about personality influence their brand personality judgments. Journal of Consumer Psychology, 22(4), 545-557.

Merabet and Benhabib (2012) Brand personality: antecedents and consequences. Indian Journal of Marketing, 11,

McCracken, G. (1986). Culture and consumption: A theoretical account of the structure and movement of the cultural meaning of consumer goods. Journal of Consumer Research, 13, 7 1-84.

Muniz, K. M. (2012). Brand Personality Dimensions in the Brazilian Context, Brazilian Administration Review (June), 168-188.

Naidoo, P. (2020). Nigeria tops south Africa as the continent's biggest economy. Retrieved from https://www.bloomberg.com/news/articles/202003-03/nigeria-now-tops-south-africa-as-thecontinent-s-biggest-economy, accessed on April 23, 2020

Nigerian Communications Commission (NCC, 2006). A Survey of Quality of Service Performance of GSM Providers in Nigeria, ICT Newspaper, 22-25.

Nigerian Communications Commission (NCC, 2020). Industry Statistics. Retrieved from https://www.ncc.gov.ng/stakeholder/statisticsreports/industry-overview\#view-graphs-tables-8, accessed on April 23, 2020

Obasan, K.A., Ariyo, O. \& Soyebo, Y. (2013) Aggressive Marketing And Product Performance In Nigeria: A Case Study Of The Telecommunication Industry. British Journal of Marketing Studies, 1, 1, pp.22-28

Oghojafor, B.E.A., Ladipo, P.K.A., Ighomereho, O.S. \& Odunewu, A.V. (2014) Determinants Of Customer Satisfaction And Loyalty In The Nigerian Telecommunications Industry. British Journal of Marketing Studies, 2, 5, pp.67-83, September 2014. Published by European Centre for Research Training 
and Development UK (www.eajournals.org) 67 ISSN 2053-4043(Print), ISSN 2053-4051(Online)

Ogilvy, D. (1983). Confessions of an advertising man. New York: Dell.

Onikoyi, I.A. \& Onikoyi, O. (2013) Studies In Corporate Communication And Brand Image. JORIND 11(2) December 2013. ISSN 1596-8303. www.transcampus.org/journals;

www.ajol.info/journals/jorind 138

Opoku, R., Abratt, R. \& Pitt, L. (2006). Communicating Brand Personality: Are The Websites Doing The Talking For The Top South African Business Schools? Journal of Brand Management 14 (1), 20-39

Pantin-sohier, G., Decrop, A., \& Brée, J. (2005). An Empirical Investigation of the Product' $s$ Package as an Antecedent of Brand Personality, 1(1), 69-80.

Pitt, L. F., Opoku, R., Hultman, M., Abratt, R., \& Spyropoulou, S. (2007). What I say about myself: Communication of brand personality by African countries. Tourism Management, 28(3), 835-844.

Plummer, J. T. (1985). How personality makes a difference? Journal of Advertising Research, 24, 2731.

Raubenheimer, J. (2004). An item selection procedure to maximise scale reliability and validity. SA Journal of Industrial Psychology, 30(4)

Sanusi, B.O., Ajilore, K. \& Oloyede, D. (2014)
Audience Perception Of The Role Of Advertising On Product Positioning And Brand Loyalty In The Nigerian GSM Market. Kuwait Chapter of Arabian Journal of Business and Management Review 3, 6; Feb. 2014, 234

Seimiene, E., \& Kamarauskaite, E. (2014). Effect of Brand Elements on Brand Personality Perception. Procedia - Social and Behavioral Sciences, 156(April), 429-434.

Shank, M. D., \& Langmeyer, L. (1994). Does personality influence brand image? Journal of Psychology, 128, 157-164.

Sheena, \& Naresh, G. (2012). Do Brand Personalities Make a Difference to Consumers? Procedia - Social and Behavioral Sciences, 37, 31-37.

Sung, Y. \& Tinkham, S.F. (2005) Brand Personality Structures in the United States and Korea: Common and Culture-Specific Factors. Journal Of Consumer Psychology, 15(4), 334-350.

Usakli, A., \& Baloglu, S. (2011). Brand personality of tourist destinations: An application of selfcongruity theory. Tourism Management, 32(1), 114127. http://doi.org/10.1016/j.tourman.2010.06.006

Valette-Florence, R., \& De Barnier, V. (2013). Towards a micro conception of brand personality: An application for print media brands in a French context. Journal of Business Research, 66(7), 897903. http://doi.org/10.1016/j.jbusres.2011.12.008

\section{Websites}

About Lagos (n.d.) Retrieved on March 14, 2016 from http://www.lagosstate.gov.ng/about-lagos/.

\section{About the Authors:}

Oladipupo Folorunsho Ajeyalemi - University of Lagos, Lagos (Nigéria). Email: oajeyalemi@unilag.edu.ng Orcid id: https://orcid.org/0000-0002-5559-6396

Bolajoko Nkemdillim Dixon-Ogbechie - University of Lagos, Lagos (Nigéria). Email: bdogbechie@unilag.edu.ng 


\title{
AVALIAÇÃO DA PERCEPÇÃO DO CLIENTE SOBRE A PERSONALIDADE DA MARCA GLOBACOM, NIGÉRIA
}

\author{
Oladipupo Folorunsho Ajeyalemi, Bolajoko Nkemdillim Dixon-Ogbechie \\ University of Lagos, Lagos (Nigéria)
}

\section{DETALHES DO ARTIGO}

\section{Histórico do Artigo:}

Recebido: 25 de Setembro de 2019

Aceito: 15 de Julho de 2020

Disponível online: 01 de Agosto de 2020

Sistema de revisão "Double blind review"

Editor Científico

Ilan Avrichir

\section{Palavras-chave:}

Personalidade da Marca

Setor de Telecomunicações

Análise Fatorial Exploratória

Análise Fatorial Confirmatória

Nigéria

\section{RESUMO}

Objetivo: (i) Desenvolver uma escala para medir a percepção do consumidor sobre a personalidade da marca no setor de telecomunicações na Nigéria, usando a metodologia de Aaker (1997). (ii) Investigue a percepção do consumidor sobre a personalidade da marca da Globacom Nigeria Limited usando a metodologia de Aaker (1997).

Método: O estudo utilizou um método quantitativo de desenho e pesquisa para amostrar 700 consumidores da indústria de telecomunicações da Nigéria. Os dados foram coletados por meio de questionário e analisados por estatística inferencial. Principais Resultados: Uma escala para medir a personalidade da marca no setor de telecomunicações da Nigéria foi desenvolvida e validada e mediu seis fatores, a saber, Sincero, Robusto, Sofisticação, Competência, Inovador e Excitação. A personalidade da marca Globacom Nigéria também foi medida.

Relevância / originalidade: $O$ estudo fornece evidências empíricas locais dos fatores de personalidade da marca do setor de telecomunicações da Nigéria. A escala desenvolvida será relevante na medição da personalidade da marca de outras marcas do setor.

Contribuições teóricas / metodológicas: o estudo apoiou o uso da metodologia de Aaker (1997) no desenvolvimento de escalas de personalidade da marca. As descobertas foram consistentes com a terminologia que poderia ser usada para descrever marcas no setor.

Contribuições sociais / Para gerenciamento: os gerentes das marcas nigerianas do setor de telecomunicações podem usar os traços identificados na comunicação de marketing para melhor apresentar suas marcas. 


\title{
UNA EVALUACIÓN DE LA PERCEPCIÓN DEL CLIENTE SOBRE LA PERSONALIDAD DE LA MARCA DE GLOBACOM, NIGERIA
}

\author{
Oladipupo Folorunsho Ajeyalemi, Bolajoko Nkemdillim Dixon-Ogbechie \\ University of Lagos, Lagos (Nigéria)
}

\section{DETALLES DEL ARTÍCULO}

Historia del Artículo:

Recibido: 25 de Septiembre de 2019

Aceptado: 15 de Julio de 2020

Disponible en línea: 01 de Agosto 2020

Double Blind Review System

Editor Científico

Ilan Avrichir

\section{Palabras-clave:}

Personalidad de Marca

Industria de Telecomunicaciones

Análisis Factorial Exploratorio

Análisis Factorial Confirmatorio

Nigeria

\begin{abstract}
RESUMEN
Objetivo: (i) Desarrollar una escala para medir la percepción del consumidor de la personalidad de la marca en la industria de las telecomunicaciones en Nigeria utilizando la metodología de Aaker (1997). (ii) Investigue la percepción del consumidor sobre la personalidad de la marca de Globacom Nigeria Limited utilizando la metodología de Aaker (1997).

Método: El estudio utilizó un diseño cuantitativo y un método de encuesta para tomar muestras de 700 consumidores de la industria de telecomunicaciones de Nigeria. Los datos se recopilaron mediante un cuestionario y se analizaron mediante estadísticas inferenciales.

Resultados principales: Se desarrolló y validó una escala para medir la personalidad de la marca en la industria de telecomunicaciones de Nigeria, que midió seis factores, a saber, sincero, robusto, sofisticado, competente, innovador y emocionante. También se midió la personalidad de marca de Globacom Nigeria.

Relevancia / originalidad: el estudio proporciona evidencia empírica local de los factores de personalidad de la marca de la industria de telecomunicaciones de Nigeria. La escala desarrollada será relevante para medir la personalidad de la marca de otras marcas dentro de la industria.

Contribuciones teóricas / metodológicas: el estudio apoyó el uso de la metodología de Aaker (1997) en el desarrollo de escalas de personalidad de marca. Los hallazgos fueron consistentes con la terminología que podría usarse para describir marcas en la industria.

Contribuciones sociales / Para la gestión: los gerentes de las marcas de la industria de telecomunicaciones de Nigeria pueden utilizar los rasgos identificados en la comunicación de marketing para presentar mejor sus marcas.
\end{abstract}

Cite it like this:

Ajeyalemi, O., \& Dixon-Ogbechie, B. (2020). An Assessment of Consumer Perception of the Brand Personality of Globacom, Nigeria. Internext, 15(3), 128-140. doi:http://dx.doi.org/10.18568/internext.v15i3.574 